\title{
The Lecithinase of Clostridium bifermentans and its Relation to the $\alpha$-toxin of Clostridium welchii
}

\author{
By ELLEN M. MILES ANd A. A. MILES \\ National Institute for Medical Research, Hampstead, London
}

SUMMARY: Clostridium bifermentans elaborates a lecithinase which induces turbidity and curding in crude lecithovitellin preparations, and hydrolyzes egg-yolk lecithin with the liberation of acid-soluble phosphate, both over a $\mathrm{pH}$ range of $5 \cdot 0-6 \cdot 3$ with a maximum in the region of $\mathrm{pH} 6 \cdot 0$. It does not induce turbidity in human serum alone, but does so in the presence of agar gels, which activate the reaction over a $\mathrm{pH}$ range of $\mathbf{5} \cdot 0-8 \cdot 0$. The activities are not dependent on the presence of $\mathrm{Ca}^{++}$ions. The enzyme responsible appears to be a lecithinase $\mathrm{C}$.

In the concentration available the lecithinase haemolysed rabbit and mouse, but not human, horse, sheep or guinea-pig red cells; and it was not lethal on intravenous injection into mice, but was slightly toxic in the skin of guinea-pigs.

The $\mathrm{Cl}$. bifermentans lecithinase $\mathrm{C}$ is antigenically related to the lecithinase $\mathrm{C}$ (the $\alpha$-toxin) of $\mathrm{Cl}$. zwelchii, though differing from the $\alpha$-toxin in its $\mathrm{pH}$ optima, haemolytic powers, independence of $\mathrm{Ca}^{++}$ions and relative non-toxicity. It is neutralized by Cl. welchii $\alpha$-antitoxin, and $\mathrm{Cl}$. bifermentans antilecithinase behaves in a reciprocal manner, neutralizing the lecithinase, necrotizing and lethal action of $\mathrm{Cl}$. zelchii $\alpha$-toxin. The antigenic relation of the two lecithinases appears to be remote.

Several species of Clostridium elaborate substances that react with normal human serum to produce turbidity or a curd of fatty material. This reaction was described by Nagler (1939) for Cl. welchii type A; in this case it is due to a lecithinase apparently identical with the $\alpha$-toxin of that species (Macfarlane, Oakley \& Anderson, 1941; Macfarlane \& Knight, 1941; van Heyningen, 1941), and the lecithinase is specifically inhibited by $\alpha$-antitoxin. The reaction may also be observed in plate cultures on agar containing human serum; a zone of turbidity develops round the growing colony. Hayward (1943) devised the plate reaction for the identification of $C l$. zelchii in mixed cultures, half the plate being impregnated with $\mathrm{Cl}$. relchii antitoxin to distinguish $\mathrm{Cl}$. welchii from other Nagler-reacting organisms. Inhibition by the antitoxin was not, however, fully specific, for the zones produced by $\mathrm{Cl}$. bifermentans, $\mathrm{Cl}$. sordellii and $\mathrm{Cl}$. centrosporogenes, unlike those of other Nagler-reacting bacilli, were substantially neutralized by the antitoxin. Indeed, the inhibition by $\mathrm{Cl}$. welchii antitoxins of a Nagler zone round colonies of readily sporing anaerobic bacilli proved to be a useful preliminary identification of $\mathrm{Cl}$. bifermentans in mixed cultures from wounds.

Most strains of $\mathrm{Cl}$. bifermentans are neither toxigenic nor pathogenic to laboratory animals; yet they appear to elaborate a lecithinase-like substance that is related antigenically to the main toxin of $\mathrm{Cl}$. welchii. The substance invited investigation, not least in the hope of illuminating the relation of lecithinase activity to toxicity in the $\alpha$-toxin of $\mathrm{Cl}$. welchii.

Our results strongly suggest that the Nagler-reacting substance of $\mathrm{Cl}$. bifermentans is in fact a lecithinase, and it will be convenient to call it so from the outset. 


\section{MATERIALS AND METHODS}

Crude bifermentans lecithinase (BL). Strain M58e of Cl. bifermentans, isolated from a war wound, was selected for its strong Nagler reactivity on human serum plates. With egg-yolk extract as prepared by Crook (1942) as indicator, and $\mathrm{m} / \mathbf{1 5}$-borate buffer $\mathrm{pH} \mathbf{7 \cdot 2}$, no lecithinase was detectable in cultures of M58e in ox-heart extract broth, cooked meat medium, or Brewer's (1940) medium. A lecithinase was produced in Macfarlane \& Knight's (1941) glucose peptone muscle-extract medium, and in rabbit liver broth (McLeod, J. W., personal communication). MeLeod's broth is a meat-extract broth to which about $10 \%$ of parboiled minced rabbit liver is added before the final autoclaving. It was chosen for lecithinase production because anaerobiosis is achieved in it without excluding air from the container. The lecithinase produced was optimally active between $\mathrm{pH} 2 \cdot 3$ and $4 \cdot 5$, and was resistant to $100^{\circ}$ for $10 \mathrm{~min}$. This proved to be a mixture of the bifermentans lecithinase with another lecithinase-like substance, and uninoculated McLeod's medium also proved to contain a heat-stable substance of the same kind capable of curding yolk extract. It was apparently released from the fragments of rabbit liver during sterilization by autoclaving, for a similar substance was obtained from parboiled mince of rabbit liver. Macfarlane \& Knight's medium, being free from lecithinase in the uninoculated state, was therefore adopted for lecithinase production. For bulk preparation, the broth at $37^{\circ}$ was seeded with one-twentieth of its volume of a vigorously growing $24 \mathrm{hr}$. cooked-meat medium culture of M58e. Lecithinase production was maximal between 8 and $18 \mathrm{hr}$. at $37^{\circ}$. The culture was usually harvested at $18 \mathrm{hr}$., partly cleared by centrifugation and filtered through a Berkefeld candle. The filtrate, which contained from 16 to 32 arbitrary lecithinase units/ml. (see p. 387), was concentrated fourfold by dialysis against glycerol in cellophan sacs, and the glycerol partly removed from the concentrate by subsequent dialysis against saline. The residual glycerol, left as a preservative, had no effect on the lecithinase activity, except slightly to enhance the rate of formation of the curd in yolk extract.

The most concentrated preparation, containing 1024 arbitrary units $/ \mathrm{ml}$., was made by Dr E. S. Duthie by pressure dialysis of Berkefeld culture filtrates in Visking sausage casing, followed by dialysis against distilled water for $24 \mathrm{hr}$. at $\mathbf{0 - 4}{ }^{\circ}$ and preserved with toluene. These preparations were stable for several months at $2^{\circ}$. Bifermentans lecithinase is symbolized in the text as BL.

Crude welchii lecithinase $(\boldsymbol{W L})$. In all, three different preparations of crude culture filtrates from $\mathrm{Cl}$. welchii type $\mathbf{A}$ were used, each from a different strain of the organism. They were concentrated by dialysis against pure glycerol at $3^{\circ}$. Welchii lecithinase is symbolized in the text as WL.

Titrations of bifermentans and welchii lecithinases (BL and $W L)$. Lecithinase activity was titrated in $8 \times 1 \mathrm{~cm}$. tubes at $37^{\circ}$; they contained four $0.25 \mathrm{ml}$. volumes of reagents : $\mathrm{BL}$ or WL preparation; $0 \cdot 85 \%$ saline or antiserum diluted in saline; M/15-acetate buffer pH 5.1; yolk extract (Crook, 1942). With weak solutions of BL, a faint turbidity developed in $3-4 \mathrm{hr}$., and curding was com- 
plete at $18 \mathrm{hr}$. The end-point was not sharp; over a four- to eightfold range of diminishing concentration, the reaction at $18 \mathrm{hr}$. declined from a thick curd floating on a clear subnatant fluid, through lesser curds on a turbid fluid, general flocculation, to faint turbidity. This gradual dose response was, however, relatively constant.

With WL, maximum titres were obtained at $6 \mathrm{hr}$; the titre was not significantly increased at $18 \mathrm{hr}$. The dose response was sharper, the 0-100\% reactions being covered in a twofold range of WL concentrations.

The unit of lecithinase (the BL and the WL unit) in both cases was arbitrarily defined as the smallest amount which, in the titration mixtures described above, would produce complete separation of the curd in $18 \mathrm{hr}$. at $37^{\circ}$; e.g. a lecithinase preparation of which $0.25 \mathrm{ml}$. produced a full curd at $1 / 16$ contains 64 units $/ \mathrm{ml}$. Our WL unit corresponded approximately to $0 \cdot 1$ mouse M.L.D. of toxin and to approximately one-twentieth of Macfarlane \& Knight's (1941) arbitrary lecithinase unit (see Table 3 ). In some simultaneous titrations, it was more convenient to use as end-point, not complete curding, but the smallest visible trace of turbidity in yolk extract. Owing to the different dose responses to BL and WL, these end-points, though in each case constantly related to the unit, are not directly comparable in terms of units.

\section{PROPERTIES OF THE CLOSTRIDIUM BIFERMENTANS LECITHINASE}

Lecithinase activity. The concentrated broth filtrates from Cl. bifermentans acted upon yolk extract, human serum, and solutions of egg-yolk lecithin. In all three cases, the activity was neutralized by specific antibody, and the reaction was not inhibited by the addition of neutralized $0.01 \mathrm{~m}$-potassium hydrogen oxalate.

\section{Table 1. Titres of a bifermentans lecithinase concentrate $(B L)$} at different $\mathrm{pH}$ values

Yolk extract in $\mathrm{M} / \mathbf{1 5}$-acetate-barbiturate buffer as substrate.

$\begin{array}{cccc}\mathrm{pH} & \begin{array}{c}\text { BL titre } \\ \text { (units } / \mathrm{ml} \text { ) }\end{array} & \mathrm{pH} & \begin{array}{c}\text { BL titre } \\ \text { (units } / \mathrm{ml} \text { ) }\end{array} \\ 3 \cdot 6 & \mathbf{2} & 6 \cdot 3 & 50 \\ 4 \cdot 2 & 5 & 7 \cdot 3 & 12 \\ \mathbf{5} \cdot \mathbf{2} & 40 & 8 \cdot 1 & 3\end{array}$

Yolk extract. Turbidity and finally curding were produced at $\mathrm{pH} 4 \cdot \mathbf{4}-\mathbf{0} \mathbf{7} \cdot \mathbf{2}$, with an optimum between $5 \cdot 0$ and $6 \cdot 4$ (Table 1 ). The yolk extract was stable over a range of $\mathrm{pH} 3 \cdot 5-8 \cdot 5$, provided that the molarity of the buffers was $0 \cdot 1$ or less. At this molarity, however, the systems tested (borate, acetate, acetatebarbiturate, phthalate, phosphate, glycine- $\mathrm{NaCl}$ ) were ineffective in varying degrees in buffering $\mathrm{BL}$ and WL concentrates, whose $\mathrm{pH}$ lay between 6.0 and $6 \cdot 5$, and to a lesser extent against yolk extract, which was usually at $\mathrm{pH} 7 \cdot \mathbf{0}-$ 7.5. For determining $\mathrm{pH}$ optima, these reagents were first brought to the desired $\mathrm{pH}$ with $\mathrm{HCl}$ or $\mathrm{NaOH}$ solutions, and diluted in the buffer. In all 
cases the $\mathrm{pH}$ of the mixtures was checked colorimetrically immediately after mixing, and when the reaction was complete. At $\mathrm{pH}$ values of over $\mathbf{5 \cdot 0}$, curding was accompanied by a shift towards lower values. The buffer effects were largely independent of the buffer salts used; $\mathrm{M} / 15$-acetate proved most convenient for general use, and for routine titrations buffer at $\mathrm{pH} 5 \cdot 1$ was employed.

In the absence of added buffer or in the presence of ineffective buffers like $\mathrm{M} / \mathbf{1 5}$-borate $\mathrm{pH} \boldsymbol{7} \cdot \mathbf{0}$, curds were produced by strong $\mathrm{BL}$ concentrates in mixtures whose overall $\mathrm{pH}$ was in the region of $\mathbf{7 \cdot 0 - 7 \cdot 5}$. It is possible that the acidity developing during the initial breakdown of lecithovitellin provided at least a sufficient local concentration of hydrogen ions for the reaction to proceed.

Human serum and the action of agar gels. Unlike WL, BL produced neither turbidity nor curding in human serum at $37^{\circ}$, whether buffered at $\mathrm{pH} 5 \cdot 1,5 \cdot 9$ or $7 \cdot 2$ with acetate buffer, or unbuffered in saline. But when strong BL was held at $37^{\circ}$ in cups cut out of unbuffered $4 \%$ agar containing $20 \%(\mathrm{v} / \mathrm{v})$ human serum of $\mathrm{pH} 7 \cdot 5-8 \cdot 5$, a marked turbidity developed to a depth of several millimetres in the agar round the cup. This striking contrast between the results of a tube and a cup-plate test depends on the presence of agar. A concentrated gel is not required; for example, a fluid mixture containing $20 \%(\mathrm{v} / \mathrm{v})$ human serum and $32 \mathrm{BL}$ units $/ \mathrm{ml}$. at $\mathrm{pH} 8.4$ remained clear for $24 \mathrm{hr}$. at $37^{\circ}$, whereas in the presence of $0.15 \%$ agar a marked turbidity developed in $2 \mathrm{hr}$.; and $0.3 \%$ induced marked curding in the same period. The effect was peculiar to BL. The same concentration of agar did not materially enhance the action of WL on human serum at $\mathrm{pH} \boldsymbol{7 \cdot 2}$, presumably because WL at this $\mathrm{pH}$ was acting within its optimal range. The gel did not adsorb inhibitory substances from the serum, and the activation was not due to soluble substances present in commercial agar; for the supernatant human serum left after centrifugation of serum-agar gels that had been held at $37^{\circ}$ for $3 \mathrm{hr}$. was as insensitive to BL as untreated human serum. It was possible also to speed up the reaction in yolk extract with agar, but the yolk extract was to a large extent unstable in its presence. We have not investigated the agar effect further; it will probably prove to depend on adsorption of one or more reactants or products of the reaction to the surface of the agar micelles in the gel.

Curding of yolk extract and the development of turbidity in human serum agar are both manifestations of BL activity; for the potencies of several BL preparations titrated against the two indicators ran strictly parallel.

Lecithin. Dr H. J. Rogers compared the BL concentrate containing 1024 units $/ \mathrm{ml}$. with a $\mathrm{Cl}$. welchii filtrate rich in $\alpha$-toxin (WL) and reports as follows.

Broth preparations liberate acid-soluble phosphate from egg yolk lecithin. Macfarlane \& Knight's (1941) method was used, except that the BL hydrolysis was conducted at $\mathrm{pH} 6 \cdot 0$ without added $\mathrm{Ca}^{++}$ions. Though hydrolysis by BL did not proceed as rapidly as that by WL, the type of lecithinase breakdown appears to be the same in both preparations (Table 2). The $\mathrm{pH}$ optimum of the BL is very broad, ranging from $5 \cdot 0$ to $6 \cdot 1$ with a maximum in the region of 6.0. The amount of phosphate liberated at $\mathrm{pH} 7 \cdot 0$ was about half that liberated at the optimum $\mathrm{pH}$. 
$\mathrm{BL}$ is not activated by $\mathrm{Ca}^{++}$ions; the degree of hydrolysis was the same with (a) no added $\mathrm{Ca}^{++} ;(b) 0.01 \mathrm{~m}-\mathrm{Ca}^{++}$added; and (c) $0.01 \mathrm{M}$-neutralized potassium hydrogen oxalate added. WL, on the other hand, was completely inhibited by the addition of the $0.01 \mathrm{M}$-oxalate.

Table 2. Liberation of phosphate from lecithin by concentrated filtrates from Clostridium bifermentans $(B L)$ and $\mathrm{Cl}$. welchii $(W L)$

\begin{tabular}{ccc} 
& \multicolumn{2}{c}{$\begin{array}{c}\text { Acid-soluble P in hydrolysate } \\
(\mathrm{mg} . / 10 \mathrm{ml} .)\end{array}$} \\
Time & $\mathrm{BL}$ & $\mathrm{WL}$ \\
$15 \mathrm{~min}$. & $0 \cdot 053$ & $0 \cdot 200$ \\
$30 \mathrm{~min}$. & $0 \cdot 080$ & $0 \cdot 398$ \\
$160 \mathrm{~min}$. & $0 \cdot 188$ & - \\
$330 \mathrm{~min}$. & $0 \cdot 347$ & -- \\
$18 \mathrm{hr}$. & 0.421 & $1 \cdot 258$
\end{tabular}

Defining the unit of lecithinase activity as the amount of enzyme which will liberate $0.1 \mathrm{mg}$. acid-soluble $\mathrm{P}$ in a defined mixture in $15 \mathrm{~min}$. at $37^{\circ}$, the $W L / B L$ ratio of activities is much smaller than the ratio of yolk extract titres (Table 3). The relatively greater activity of BL in yolk extract might be due to other enzymes. Proteases, for example, can produce turbidity in yolk extract (E. S. Duthie, personal communication) and the BL proved to contain a protease highly active against egg yolk proteins. But the addition of a filtrate

Table 3. The relative activities of concentrated filtrates from Clostridium bifermentans $(B L)$ and $\mathrm{Cl}$. welchii $(W L)$

\begin{tabular}{|c|c|c|c|}
\hline \multirow{2}{*}{\multicolumn{2}{|c|}{ Units }} & Preparation & \multirow{2}{*}{$\begin{array}{l}\text { Ratio of } \\
\text { activities }\end{array}$} \\
\hline & & WL & \\
\hline $\begin{array}{l}\text { Lecithinase units/ml. } \\
\text { (Macfarlane \& Knight, 1941) }\end{array}$ & $\left\{\begin{array}{l}\mathrm{pH} 6 \cdot 0 \\
\mathrm{pH} 7 \cdot 0\end{array}\right.$ & $\begin{array}{r}500 \\
\text { c. } 500\end{array}$ & $\begin{array}{r}943: 1 \\
2000: 1\end{array}$ \\
\hline $\begin{array}{l}\text { Yolk extract units/ml., } \\
\text { (Miles \& Miles) }\end{array}$ & 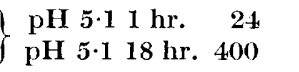 & $\begin{array}{r}8,000 \\
12,000\end{array}$ & $\begin{array}{r}333: 1 \\
30: 1\end{array}$ \\
\hline Mouse M.L.D. (intravenous) & $<1$ & 1,200 & $>1200: 1$ \\
\hline
\end{tabular}

from Chromobacterium prodigiosum, highly active in digesting casein, to graded dilutions both of BL and WL, did not increase the yolk-extract titres, though significant proteolysis of the egg-yolk proteins was demonstrable in a control mixture of prodigiosum filtrate and yolk extract. The discrepancy in the lecithin and yolk-extract ratios is more probably attributable to other factors. For example, if the bifermentans lecithinase were more stable than the welchii lecithinase in high dilution, the yolk extract titres of $\mathbf{B L}$ at $18 \mathrm{hr}$. would be disproportionately high; or different degrees of substrate-enzyme dissociation or of inhibition by end-products of the reaction might account for differences in the rates of appearance of curds in yolk extract after an arbitrarily selected period of hydrolysis at $37^{\circ}$.

It may be concluded that the turbidity in egg yolk produced by preparations of a $\mathrm{Cl}$. bifermentans filtrate $(\mathrm{BL})$ results from the action of a lecithinase $\mathrm{C}$ - 
that is, a lecithinase of the same type as that formed by $\mathrm{Cl}$. welchii but that the $18 \mathrm{hr}$. yolk extract titres are probably gross overestimates of the enzyme potency of $\mathrm{BL}$, as compared with WL.

Stability. Both glycerinated BL and concentrated, pressure-dialyzed preparations retained their activity against yolk extract for over 6 months at $\mathbf{2}^{\circ}$. The enzyme is comparatively heat stable. A preparation containing $128 \mathrm{BL}$ units $/ \mathrm{ml}$. lost $50 \%$ of its activity on heating to $100^{\circ}$ for $10 \mathrm{~min}$. at $\mathrm{pH} 6 \cdot 5$.

Moderate degrees of shaking do not affect the enzyme, but it is susceptible to oxidation; a weak solution of $\mathrm{BL}$ ( 8 units $/ \mathrm{ml}$.) was not affected by $2 \mathrm{hr}$. vigorously bubbling $\mathrm{N}_{2}$, but lost $50 \%$ of its activity on exposure for $2 \mathrm{hr}$. at room temperature to $\mathrm{I} / \mathbf{1 5 0} 20$ vol. $\mathrm{H}_{2} \mathrm{O}_{2}$.

The following antiseptics were added to BL (32 units/ml.) for $\mathbf{2 4} \mathrm{hr}$.: excess of toluene and chloroform, $0.25 \%$ formalin, $0.5 \%$ phenol, and $1 / 10,000$ merthiolate. None had any significant effect on the BL titre of the preparation. BL may be preserved for several months at $2^{\circ}$ under toluene without loss of activity.

Haemolysis. BL preparations at $\mathrm{pH} 7 \cdot 0$ containing $\mathbf{2 5 6}$ units $/ \mathrm{ml}$. were tested against $5 \%$ (volume of packed centrifuged cells/vol. saline) human, horse, sheep, rabbit, guinea-pig and mouse red cells. No haemolysis was seen after $2 \mathrm{hr}$. at $37^{\circ}$ and overnight at room temperature, excepting in the rabbit and mouse cells, $50 \%$ of which were lysed by a final concentration of $64 \mathrm{BL}$ units $/ \mathrm{ml}$. The lysis was inhibited by $\mathrm{Cl}$. welchii $\alpha$-antitoxin. The haemolysis observed on horse blood agar plates round colonies of $C l$. bifermentans does not appear to be due to the lecithinase; for not all lecithinase-producing strains are haemolytic, and the haemolytic activity of lecithinase-producers is not affected by strong anti-lecithinase sera.

Toxicity. BL was non-toxic to mice by the intravenous route in doses corresponding to $512 \mathrm{BL}$ units, which are equivalent to about $0 \cdot 5$ /lecithinase units of Macfarlane \& Knight (1941) and, on this basis, equivalent to $0.5 \mathrm{ml}$. of $\mathrm{Cl}$. welchii toxin at $\mathrm{pH} 7 \cdot 0$. Doses of $100 \mathrm{BL}$ units in $0 \cdot 1 \mathrm{ml}$. produced no more than a transient inflammation on intradermal injection in rabbits and guinea-pigs, whereas the corresponding amount of $\mathrm{Cl}$. welchii $\alpha$-toxin, in terms of Macfarlane \& Knight's units, produced a marked inflammatory lesion with central necrosis. The simultaneous injection of $1 / 50,000$ adrenaline to prevent dispersal of the injected material (Mason, 1936) enhanced the skin toxicity of this dose of $\mathrm{BL}$; after $\mathbf{2 4} \mathrm{hr}$. lesions were on the average $12 \mathrm{~mm}$. in diameter, slightly inflamed, with a central whitish area $5 \mathrm{~mm}$. in diameter, which became scabbed in 3 days; the inflammation was significantly diminished when the BL was mixed with strong $\alpha$-antitoxin before injection.

In summary, BL is a lecithinase differing from the WL in rate of hydrolytic action in its $\mathrm{pH}$ optimum, independence of activation by $\mathrm{Ca}^{++}$ions, and relative non-toxicity for experimental animals (Table 3 ). Its activity can be titrated by the development of turbidity in yolk extract or in human serum agar, though the relation of titre to degree of hydrolysis of lecithin differs substantially from that of $\mathrm{Cl}$. welchii lecithinase. Like WL, BL is a lecithinase C. Its antigenic relationship to WL is discussed in the following section. 


\section{THE IMMUNOLOGICAL RELATION OF CL. BIFERMENTANS \\ LECITHINASE AND $C L$. WELCHII $\alpha$-TOXIN}

The anti-BL potency of therapeutic $C l$. welchii antisera used in Nagler tests is roughly proportional to their $\alpha$-antitoxin content (Dr Nancy J. Hayward, personal communication). Horse antitoxins also contain antibodies to other antigenic components of $\mathrm{Cl}$. welchii, and to other bacilli. These antibodies may have been induced naturally, or as the result of the various inoculations to which the horses are subjected. Consequently in such heterogeneous antisera the only reliable indication that the anti-BL and anti-WL action is due to the same antibody is that the anti-BL:anti-WL ratio of potencies should be constant in a large number of sera from different animals; for it is unlikely that two antibodies would be present in the same relative concentration in the sera of a number of horses.

\section{Source of the antisera}

Cl. welchii. In all, twenty-four horse antisera containing $\mathrm{Cl}$. welchii $\alpha$-antitoxin were tested. They were mainly single bleedings, each from a different horse, and most of them were 'native' (i.e. unrefined). The results with antisera refined either by ammonium sulphate precipitation or partial proteolytic digestion or with a few native sera dried and reconstituted, did not differ significantly from those obtained with native sera.

Cl. bifermentans. Rabbits were selected whose sera contained no detectable anti-WL or anti-BL activity. They received a thrice-weekly intraperitoneal injection of $2 \mathrm{ml}$. of a $7 \mathrm{hr}$. living culture of $\mathrm{Cl}$. bifermentans, containing about $50 \mathrm{BL}$ units. The living culture produced no ill-effects. After two 4-weekly courses weak sera were obtained of which $1 \mathrm{ml}$. neutralized 40-80 BL units. An attempt to improve the antigenicity of the weak BL preparations by alumprecipitation was unsuccessful. Several months later, the same rabbits received six to nine thrice-weekly injections of a concentrated BL containing 2000 units. Sera harvested $7-10$ days after the last injection neutralized $5000 \mathrm{BL}$ units $/ \mathrm{ml}$.

\section{Precipitin tests}

The strong $\mathrm{Cl}$. bifermentans antilecithinase sera reacted strongly with BL preparations, giving a typical zone of specific optimal precipitation in a constant-antibody titration; they failed to precipitate WL. Strong Cl. welchii antitoxins precipitated WL, but not BL.

\section{Titration of anti-lecithinase sera}

(a) Against growing plate cultures. Falling dilutions of antisera were incorporated in Petri dishes of Fildes's (1920) medium, containing $4 \%$ agar. The plates, together with a control containing normal serum, were seeded with four strains of $\mathrm{Cl}$. bifermentains and of $\mathrm{Cl}$. welchii, each in one spot. The end-point was taken as the full neutralization of the Nagler zone round growing colonies after 24 and $48 \mathrm{hr}$. incubation. Estimation of the bifermentans end-points was complicated by the presence of faint unneutralized zones of turbidity. Ten 
horse sera, whose $\alpha$-antitoxin content ranged from 0 to $4800 \mathrm{i} . \mathrm{u} . / \mathrm{ml}$. were compared with normal rabbit serum in this way. Only two strong $\alpha$-antitoxins neutralized the BL as well as the WL zones, giving anti-BL:anti-WL ratios of $1: 16$ and $1: 64$. The method was abandoned, partly because high concentrations of antiserum could not be achieved in the agar, and partly because the amount of lecithinase produced by a growing colony was not a satisfactory standard against which to measure the anti-lecithinase potency of the sera.

(b) Against yolk extract in tubes. Falling dilutions of antisera in $0.25 \mathrm{ml}$. were mixed with $2 \mathrm{BL}$ or $2 \mathrm{WL}$ units in $0 \cdot 25 \mathrm{ml}$. and held at $37^{\circ}$ for $30 \mathrm{~min}$.; $0.25 \mathrm{ml}$. of $\mathrm{m} / 15$-acetate buffer $\mathrm{pH} 5.2$ and of yolk extract were added and the result read after $18 \mathrm{hr}$. at $37^{\circ}$.

The dilutions of the test sera were made as accurately as possible. Taking the appearance of even slight degrees of turbidity as evidence of lecithinase activity, the neutralization of 2 BL units was far from sharp, rising from 0 to $100 \%$ over a 32 -fold range of serum dilutions (see Table 4 ).

\section{Table 4. The neutralization of $B L$ and $W L$ in constant proportions by Clostridium welchii antitoxin $\boldsymbol{S} \mathbf{1}$}

$(t), t, t^{+}, t^{++}=$degrees of turbidity, trace to marked opacity; $t^{+++}=$visible flocculation. $\mathrm{C} 3, \mathrm{C} 4$, etc. $=$ floating curd and its thickness in $\mathrm{mm} .18 \mathrm{hr}$. readings at $37^{\circ}$.

\begin{tabular}{|c|c|c|c|c|c|c|c|c|}
\hline \multirow{2}{*}{$\begin{array}{c}\text { Enzyme } \\
\text { preparation }\end{array}$} & \multicolumn{8}{|c|}{ Dilution of $\alpha$-antitoxin } \\
\hline & $1 / 20$ & $1 / 40$ & $1 / 80$ & $1 / 160$ & $1 / 32$ & $1 / 640$ & $1 / 1,280$ & Control \\
\hline BL 2 units & 0 & $(\mathbf{t})$ & $\mathbf{t}$ & $t^{+}$ & $\mathbf{t}^{+}$ & $\mathbf{t}^{+++}$ & $\mathrm{C3}$ & $\mathrm{C}_{4}$ \\
\hline BL, 1 unit & 0 & 0 & $(\mathrm{t})$ & $t$ & $t$ & $t^{+}$ & $t^{++}$ & $\mathrm{C} 3$ \\
\hline \multirow[t]{3}{*}{ BL $\frac{1}{2}$ unit } & 0 & $\mathbf{0}$ & 0 & $(\mathbf{t})$ & (t) & $\mathbf{t}$ & $t$ & C 1 \\
\hline & \multicolumn{8}{|c|}{ Dilution of $\alpha$-antitoxin } \\
\hline & $1 / 500$ & $1 / 1,000$ & & 00 & 000 & $1 / 8,000$ & $1 / 16,000$ & Control \\
\hline WL 2 units & 0 & 0 & & & 6 & C6 & C6 & $\mathrm{C} 6$ \\
\hline WL 1 unit & 0 & 0 & & & 3 & C 6 & $\mathrm{C} 6$ & C6 \\
\hline WL $\frac{1}{2}$ unit & 0 . & 0 & & & 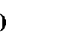 & C3 & $\mathrm{C} 4$ & $\mathrm{C} 4$ \\
\hline
\end{tabular}

Nevertheless, defining the end-point as the highest completely inhibiting dilution, repeated titrations with a given serum gave consistent results, and neutralization occurred in constant proportions of lecithinase and antilecithinase, as in Table 4, which records a result typical of six $\mathrm{Cl}$. welchii antitoxins. But though with a given serum the results were consistent, the range of the 0-100\% response, and particularly the point within the range at which curding appeared, varied with each serum tested. Thus for antiserum S1 in Table 4, the range was 32 -fold $(1 / 40$ to $1 / 12,800)$ and curds were formed over a twofold range (1/640 and 1/1280). With antiserum S10 (Table 5), the range was also 32 -fold (1/80-1/2560), but curding took place over an eightfold range (1/300-1/2560). In contrast the neutralization of $2 \mathrm{WL}$ units was sharp, and the dose responses similar.

With the six antitoxins, the anti-BL:anti-WL ratios lay at random between 1:25 and 1:400 (Table $5(a)$ ) irrespective of the anti-WL potency of the sera, 
or of their state, i.e. native or refined. Repeated titrations with another preparation of BL gave substantially the same results; but with ten native antitoxins included at the same time (Table $5(b)$ ) the ratios all lay between $1: 20$ and $1: 80$.

Table 5. Tube titrations of Clostridium welchii $\alpha$-antitoxins against 2 BL and 2 WL units

Titres, $18 \mathrm{hr}$. Reciprocal of antiserum dilution

\author{
Cl. welchii \\ $\alpha$-antitoxins
}

(a) $\mathrm{S} 1$ $\mathrm{S} 10$

G.W.P. $1100 / 36$

G.W.P. 401

K 17

G.G. (Toronto)

(b) $\mathrm{S} 11$

$\mathrm{S} 12$

$\mathrm{S} 13$

S 14

S15

S 16

$\mathrm{S} 17$

$\mathrm{S} 18$

S 19

$S 20$

$\begin{array}{cc}\text { anti-BL } & \text { anti-WL } \\ 20 & 1000 \\ 40 & 2000 \\ 10 & 4000 \\ 10 & 4000 \\ 40 & 1000 \\ 10 & 2000\end{array}$

$400 \quad 1: 40$

$400 \quad 1: 20$

$800 \quad 1: 40$

$400 \quad 1: 40$

$800 \quad 1: 40$

$800 \quad 1: 40$

$400 \quad 1: 20$

$800 \quad 1: 20$

$800 \quad 1: 80$

$400 \quad 1: 40$

It will be evident that the variations of dose-response in the anti-BL titrations and the difficulty of estimating the $0 \%$ neutralization end-point could produce widely varying ratios, even though the anti-BL and anti-WL effects were due to the same antibody. By analogy with titrations of antitoxins in animals, sharper dose responses should be obtained by using a larger amount of BL in the titrations; and this proved to be the case with strong antisera. The method was however inapplicable to all the sera because the antiBL titres of the sera were so low that neutralization of concentrated BL would have taken place only in neat or $1 / 2$ serum; i.e. dilutions in which non-specific interference with curding of yolk extract may occur. In the hope of obtaining sharper end-points with stronger BL, and yet avoiding non-specific inhibition, we devised a cup-plate method of titration.

(c) Against human serum in cup-plates. Mixtures of equal volumes of antiserum dilutions and WL or BL were held at $37^{\circ}$ for $30 \mathrm{~min}$. Holes $7 \mathrm{~mm}$. in diameter were punched in plates of $4 \%$ agar in unbuffered saline containing $20 \%$ of a strongly Nagler-reacting human serum; these were filled with $0.06 \mathrm{ml}$. of the reacting mixtures. After $20 \mathrm{hr}$. at $37^{\circ}$, the end-point was taken as the smallest dilution of serum completely neutralizing the zone of turbidity round the cup.

Yolk extract can replace human serum; but serum is preferable, since the agar is initially more transparent. In human serum agar, the non-specific inhibition observed in tube reactions with native, undiluted normal horse o 
rabbit sera did not take place, or was minimal; the width of the turbidity zone was sometimes diminished by $0.5 \mathrm{~mm}$., but its intensity was equal to that round the control cup.

As in the tube titrations, for a given antiserum the proportions of lecithinase and anti-lecithinase in just neutral mixtures was constant for an eightfold range of lecithinase concentration. Good zones, 3-5 mm. in width, were produced by preparations containing $8 \mathrm{WL}$ units or $32 \mathrm{BL}$ units $/ \mathrm{ml}$. With the proportionally larger dose of $\mathrm{BL}$, the neutralizing end-points were much sharper, and the estimated anti-BL potency of the sera greater than those obtained by tube titrations. The anti-WL potency measured in the cup-plates was slightly higher. For these reasons, and because different amounts of BL and WL were used, the cup-plate potency ratios are not directly comparable with the tube potency ratios.

Twenty welchii antitoxins, including the sixteen listed in Table 5, were titrated against equal volumes of $\mathrm{WL}$ and $\mathrm{BL}, 16$ and 64 units $/ \mathrm{ml}$. respectively. The distribution of anti-BL:anti-WL ratios is shown in Table 6. Having regard to the fact that the titres were obtained with twofold dilutions of antitoxins, the similarity of ratio for all the sera tested provides substantial evidence for the neutralization of the two lecithinases by one antibody.

Table 6. Cup-plate titrations of twenty Clostridium welchii $\alpha$-antitoxins against $B L$ and $W L$ : the distribution of anti-BL:anti-WL ratios

$\begin{array}{cc}\begin{array}{c}\text { Ratio } \\ \text { anti-BL }: \text { anti-WL }\end{array} & \begin{array}{c}\text { No. of } \\ \text { antitoxins }\end{array} \\ 1: 2 \cdot 5 & 2 \\ 1: 4 & 3 \\ 1: 5 & 9 \\ 1: 10 & 6\end{array}$

In cup-plate titrations, the anti-BL:anti-WL ratios of four strong rabbit Cl. bifermentans anti-lecithinase sera were 8:1, 10:1, 16:1 and 16:1. Since all the rabbits were free of antilecithinase before immunization, the fact that the antisera neutralize both lecithinases establishes that the $\alpha$-toxin of $\mathrm{Cl}$. welchii is related to some antigenic constituent of $\mathrm{Cl}$. bifermentans, and the similarity of the ratios suggests that the constituent is its lecithinase.

The antitoxic properties of Clostridium bifermentans antilecithinase

The most forceful proof of the antigenic relation of BL and WL lies in the fact that bifermentans antilecithinase sera neutralize the necrotic and lethal action of $\mathrm{Cl}$. welchii $\alpha$-toxin and that immunization with BL confers an active immunity to the $\alpha$-toxin. Two $\mathrm{Cl}$. welchii toxins, one a glycerinated concentrate (290), the other a dried toxin precipitated from filtrates by ammonium sulphate (Welchpool) were used. Table 7 summarizes the passive protection tests in 18-22 g. mice. Equal volumes of toxins and antisera were held at room temperature 3-4 hr., and injected intravenously in $0 \cdot 4 \mathrm{ml}$. doses. Neat anti-bifermentans serum 2737 neutralized about $4 \mathrm{LD}_{50}$ of the Welchpool toxin, and diluted serum was proportionally active. Two other anti-bifermentans sera, 
2717 and 2736 , neutralized toxin 290 , and their effect was proportional to their anti-BL titres, which were in the ratio $1: 2$. Two normal rabbit sera, and four other control rabbit sera, antisera to Proteus vulgaris and Brucella melitensis, were not antitoxic. In view of the consistently sharp dose response of mice to these preparations of $\alpha$-toxin (D. G. Evans, personal communication) these results are significant.

Table 7. The protective action of Clostridium bifermentans antilecithinase against $\mathrm{Cl}$. welchii $\alpha$-toxin, injected intravenously in mice.

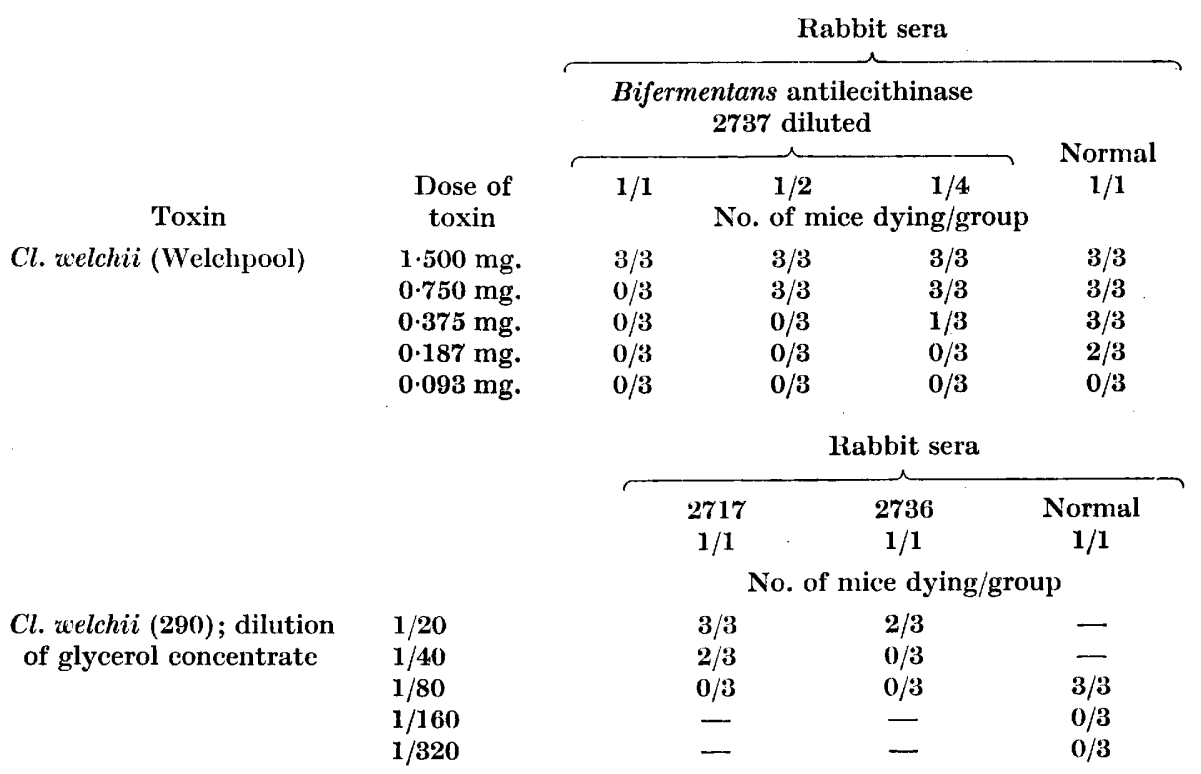

The bifermentans antilecithinase sera 2717 and 2718 and normal rabbit serum were each mixed with equal volumes of graded dilutions of the toxin (290) and, after standing at $37^{\circ}$ for $3 \mathrm{hr}$., $0 \cdot 1 \mathrm{ml}$. of the mixtures were injected intradermally in four $200 \mathrm{~g}$. guinea-pigs. The average reaction after $24 \mathrm{hr}$. to $1 / 100$ toxin was an inflammatory area $22 \mathrm{~mm}$. in diameter, with a central whitish necrotic area $5-8 \mathrm{~mm}$. in diameter; and to $1 / 400$ toxin, a slightly inflamed area $10 \mathrm{~mm}$. in diameter. The normal rabbit serum did not modify these reactions significantly, but with both antisera the reactions to a mixture of 1/100 toxin and antilecithinase were equivalent to those of $1 / 400$ toxin alone, indicating a four-fold reduction in toxicity.

Active cross immunity was determined in two of the rabbits, 2717 and $\mathbf{2 7 1 9}$, used in the preparation of the $\mathrm{Cl}$. bifermentans antisera. They were each given a boosting dose of 1024 BL units intraperitoneally and 3 weeks later, when their sera neutralized respectively 1280 and $320 \mathrm{BL}$ units $/ \mathrm{ml}$., they were depilated, and graded amounts of $\mathrm{Cl}$. welchii toxin (Welchpool) in $\mathbf{0 . 2} \mathrm{ml}$. were injected intradermally. Two normal rabbits of about the same weight were also injected. Using either the overall area of gross oedema and inflammation or the central 
area of necrosis (Table 8 ) as a measure of toxicity, it was strikingly evident after both 1 and 2 days that the rabbits immunized with BL were protected against the $\mathrm{Cl}$. welchii $\alpha$-toxin.

Table 8. The active immunization of rabbits 2717 and 2719 by Clostridium bifermentans lecithinase (BL) against $\mathrm{Cl}$. welchii $\alpha$-toxin. Inhibition of skin necrosis 2 days after intradermal injection of toxin

\begin{tabular}{ccccc}
$\begin{array}{c}\text { Dose of } \\
\text { Welchpool toxin }\end{array}$ & \multicolumn{4}{c}{ Area in sq.mm. of skin necrosis in rabbits } \\
$\begin{array}{ccccc}(\mathrm{mg}) \\
2 \cdot 000\end{array}$ & 2717 & 2719 & Control 1 & Control 2 \\
1.000 & 10 & 34 & 205 & 490 \\
0.500 & 10 & 13 & 173 & 265 \\
$0 \cdot 250$ & - & 3 & 105 & 94 \\
$0 \cdot 125$ & - & - & 93 & 55 \\
0.063 & - & - & 64 & 50 \\
0.031 & - & - & 39 & 20 \\
0.016 & - & - & - & -
\end{tabular}

A dried preparation of $\mathrm{Cl}$. sordellii toxin, which proved to contain about $33 \mathrm{BL}$ units/mg., was tested to ascertain the independence of its lethal action and lecithinase activity. The toxicity was not affected by normal rabbit serum, Cl. welchii $\alpha$-antitoxin (4000 i.u./ml.) or by a bifermentans antilecithinase containing 5000 anti-BL units/ml. (Table 9).

Table 9. Absence of protective action of Clostridium bifermentans antilecithinase 2717 and $\mathrm{Cl}$. welchii $\alpha$-antitoxin $S \mathrm{I}$ against $\mathrm{Cl}$. sordellii toxin

\begin{tabular}{|c|c|c|c|c|}
\hline \multirow{3}{*}{$\begin{array}{c}\text { Sordellii } \\
\text { toxin } \\
\text { (dose in mg.) }\end{array}$} & & \multicolumn{3}{|c|}{ Serum } \\
\hline & Nil & $\begin{array}{c}\text { Normal } \\
\text { rabbit }\end{array}$ & $\begin{array}{c}\text { Anti- } \\
\text { bifermentans }\end{array}$ & $\begin{array}{l}\text { Anti- } \\
\text { welchii }\end{array}$ \\
\hline & & No. of $\mathrm{m}$ & dying/group & \\
\hline $0 \cdot 020$ & $3 / 3$ & $3 / 3$ & $3 / 3$ & $3 / 3$ \\
\hline $0 \cdot 010$ & $2 / 3$ & $3 / 3$ & $2 / 3$ & $3 / 3$ \\
\hline $0 \cdot 005$ & $0 / 3$ & - & - & - \\
\hline
\end{tabular}

\section{DISCUSSION}

The serological evidence that both in $\mathrm{Cl}$. welchii $\alpha$-antitoxins and in $\mathrm{Cl}$. bifermentans antilecithinase sera one antibody is responsible for neutralizing the two lecithinases has been presented at some length. It was not practicable with the material at our disposal to perform complete 'mirror' tests with antiscra to the two lecithinases prepared ad hoc. For the exploration of $\mathrm{Cl}$. welchii antisera we had to rely on the less satisfactory method of analysing heterogeneous horse antitoxins, which provides only indirect evidence of antigenic similarity. This proved to be difficult, for with certain sera the tube and cup-plate titrations, and consequently the ratios, were not consistent. The inconsistency lay chiefly in the fluctuation of the anti-BL titres in the tube as compared with those in the cup-plate. In the cup-plate, the substrate is 
reached only by diffusion of the enzyme-antiserum mixtures into the agar gel; it is probable that free enzyme in such mixtures diffuses more rapidly than enzyme-antibody complexes, whereas in the tube, the substrate is in contact with, and perhaps competes with the antibody for the enzyme during the incubation of the mixtures. As the result of some unpublished experiments on the inhibition of antilecithinase sera by the addition of the yolk extract indicator at varying intervals after mixing lecithinase and antiserum, we concluded that competition occurred both with BL and WL; and in a recent paper Zamecnik \& Lipmann (1947) have clearly demonstrated such competition in $\mathrm{Cl}$. welchii lecithinase-antilecithinase systems. It is significant that the discrepant titres occurred only in the heterologous system-a Cl. welchii antibody and a $\mathrm{Cl}$. bifermentans antigen-and may be attributable to wide variations in avidity of the antibody for heterologous antigen; variations which are minimized in the peculiar conditions of the cup-plate. Whatever the explanation of the difference, we have accepted the cup-plate titre as a trucr measure of the combining power of the antitoxins because end-points were measurable with greater accuracy and non-specific inhibition of curding by undiluted and moderately diluted sera was minimal. Morcover, the evidence of the more consistent cup-plate ratios accords with the direct evidence that known bifermentans antilecithinase neutralized the $\alpha$-toxin of $\mathrm{Cl}$. zelchii.

Our hope that such an antibody might throw light on the relation of lecithinase-activity to toxicity in the $C l$. welchii $\alpha$-toxin has not been fulfilled. The parallelism of lecithinase and toxicity in preparations of this toxin indicates that the two activities are consistently carried on one particle. If, as Macfarlane \& Knight (1941) suggested, the lecithinase confers haemolytic and necrotic powers on the $\alpha$-toxin, then the bifermentans antilecithinase should be antitoxic. But the fact that the bifermentans antilecithinase is antitoxic does not prove the identity of toxic and enzymic groups; for antibody combining with the lecithinase groups alone might mask adjacent toxic groups in the $\alpha$-toxin particle; or the specificity of bifermentans antilecithinase for $\alpha$-toxin may be accidental in that it is determined neither by the lecithinase nor the toxic group on the $\alpha$-toxin particle, but by another determinant, common to both enzymes.

Only a substantial independence of neutralization by bifermentans antilecithinase of the lecithinase activity and the toxicity of the $\alpha$-toxin would have given positive evidence that the two activities were referable to different groups on the particle.

From the fact that among all the lipids they tested, only lecithin was fully effective in interfering with the combination of $\mathrm{Cl}$. welchii lecithinase and $\alpha$-antitoxin, Zamecnik \& Lipmann (1947) concluded that the interference was due, not to a non-specific coating of the enzyme by the lecithin, but to competition of lecithin and antibody for the same region of the enzyme molecule. But the demonstration of such inhibition does not necessarily solve the problem of the identity of the hypothetical enzymic and toxic groups in the molecule, for a steric interference with the toxic group might follow a specific adsorption of lecithin to an adjacent non-toxic enzyme group. 
Nevertheless, the properties of the bifermentans lecithinase itself throw some doubt on the assumption that lecithinase activity per se is sufficient to account for the lethal and necrotic powers of the $\alpha$-toxin. The bifermentans lecithinase, in doses sufficient to liberate as much acid-soluble phosphate from lecithin as 0.5 M.I.D. of $\alpha$-toxin at $\mathrm{pH} 7 \cdot 0$, was completely non-toxic on intravenous injection in mice, and only mildly inflammatory in the skin of guinea-pigs. At the $\mathrm{pH}$ of the tissues, the bifermentans lecithinase, unlike $\alpha$-toxin, is working well outside its optimal $\mathrm{pH}$ range though, as the in vitro activation of the lecithinase at non-optimal $\mathrm{pH}$ values by an agar gel demonstrates, the overall $\mathrm{pH}$ condition may be irrelevant provided that certain physico-chemical conditions are satisfied. We have no means of deciding whether these conditions are realized in the tissues; and, moreover, the argument can be applied equally well to the $\alpha$-toxin of $\mathrm{Cl}$. welchii. But the possibility of such activation suggests that the difference between a toxic and a non-toxic lecithinase of the same apparent enzyme type may reside either in a readiness of absorption to ccrtain tissue structures that is independent of the actual lecithinase activity, or in the presence in the body of activators to one but not the other lecithinase.

These speculations can be fully tested only when we have prepared a bifermentans lecithinase whose phosphate-liberating activity is equivalent to that of at least 10 m.L.D. of $\mathrm{Cl}$. zeelchii $\alpha$-toxin.

The similarity of the $\mathrm{pH}$ optima suggests that the curding of egg yolk extract and the liberation of phosphate from lecithin are manifestations of the same enzymic process; and the neutralization of both by $\mathrm{Cl}$. welchii $\alpha$-antitoxin, which is unlikely to contain antibodies to two different enzymes of $\mathrm{Cl}$. bifermentans, suggests that a protease does not contribute to the curding. The greater sensitivity of the yolk extract to bifermentans lecithinase measured in terms of phosphate-liberation, compared with its sensitivity to welchii lecithinase, is most probably due to the greater stability of the bifermentans lecithinase in the enzyme-substrate mixture; for the ratio of yolk extract titres in a given preparation at $1 \mathrm{hr}$. is of the same order as the ratio of phosphate-liberating power ('Table 3 ) and the discrepancy develops only after many hours' incubation.

The two lecithinases are too dissimilar in their rates of action on the yolk extract and the various lecithinase preparations were too impure to permit any speculation about the relative amount of enzyme protein which they contained. Hence it is not possible to translate the ratio of anti-BL:anti-WL potencies into a measure of the degree of antigenic relationships of the two lecithinases. But the fact that BL and WL precipitate strongly with their respective homologous antisera, and that cross-precipitation is absent or feeble, suggests that the relation is fairly remote.

The conclusions with regard to $\mathrm{Cl}$. bifermentans apply equally to $\mathrm{Cl}$. sordellii and $\mathrm{Cl}$. centrosporogenes. As far as our experience goes, we agree with Clark \& Hall (1937) and Stewart (1938) that these two bacilli are probably identical with $\mathrm{Cl}$. bifermentans, and that $\mathrm{Cl}$. sordellii is a toxigenic variety of the species. Their similarity is further emphasized by their production of Nagler-reacting substances all of which are neutralized by $\alpha$-antitoxin (Hayward, 1943) and by 
the antilecithinase of Cl. bifermentans. Both Clark \& Hall and Stewart record slight neutralization of the sordellii toxin by $\mathrm{Cl}$. bifermentans antisera. If $\mathrm{Cl}$. sordellii is a variety of $\mathrm{Cl}$. bifermentans we may expect that some strains of Cl. bifermentans will elaborate the sordellii toxin in amounts so small as to be detectable only by the specific antibody response in an animal after a course of immunization; and in these instances the immunizing suspensions used may well have been prepared from a strain of this kind. Antisera to our strain M58e had no such antitoxic effect, and neutralization tests showed quite clearly the independence of the $c l$. sordellii lecithinase and toxin.

We are greatly indebted to Dr H. J. Rogers for his examination of our lecithinase concentrate; to Dr E. S. Duthie for concentrating a preparation by pressure dialysis; and to Dr C. L. Oakley and Dr A. F. B. Standfast for their supply of horse antitoxins.

\section{REFERENCES}

Brewer, J. H. (1940). Clear liquid mediums for the 'aerobic' cultivation of anaerobes. J. Amer. med. Ass. 115, 598.

Cuark, F. E. \& Hate, I. C. (1937). A comparative study of Bacillus bifermentans ('Tissier \& Martelly), Bacillus centrosporogenes (Hall) and certain closely related proteolytic anaerobes. J. Bact. 33, 23.

Crook, E. M. (1942). The Nagler reaction: the breakdown of lipoprotein complexes by bacterial toxins. Brit. J. exp. Path. 23, 37.

Firdes, P. (1920). A new medium for the growth of B. influenzae. Brit. J. exp. Path. $1,129$.

HAYward, N. J. (1943). The rapid identification of $\mathrm{Cl}$. welchii by Nagler tests in plate cultures. J. Path. Bact. 55, 285.

Heyningen, W. E. van (1941). The biochemistry of the gas-gangrene toxins. 2. Partial purification of the toxins of $\mathrm{Cl}$. zelchii type A. Separation of $\alpha$ - and $\theta$-toxins. Biochem. J. 35, 1257.

Macfartane, M. G. \& Knigit', B. (. J. G. (1941). The biochemistry of bacterial toxins. 1. The lecithinase activity of Cl. welchii toxins. Biochem. J. 35, 884.

Macfarlane, R. G., Oakley, C. L. \& Anderson, C. G. (1941). Haemolysis and the production of opalescence in serum and lecitho-vitellin by the $\alpha$-toxin of Clostridium reelchii. J. Path. Bact. 52, 99.

Mason, J. H. (1936). The toxin of Clostridium chanvoei. Onderstepoort J. vet. Sci. 7, 433.

Nagler, F. P. O. (1939). Observations on a reaction between the lethal toxin of $\mathrm{Cl}$. reelchii (type A) and human serum. Brit. J. exp. Path. 20, 473.

Stewart, S. E. (1938). The titration of bifermentans antitoxin and the relationship between Clostridium bifermentans and Clostridium sordellii. J. Bact. 35, 13.

ZAMEcnik, P. C. \& Lipmann, F. (1947). A study of the competition of lecithin and antitoxin for $\mathrm{Cl}$. zelchii lecithinase. J. exp. Med. 85, 395. 